\title{
Expansion of glass waste by the double effect of liquid and solid foaming agents for manufacturing the cellular glass gravel (CGG) in a $10 \mathrm{~kW}$-microwave oven
}

Expandarea deșeului de sticlă prin dublul efect al agenților de spumare lichid și solid pentru fabricarea pietrișului din spumă de sticlă (CGG) întrun cuptor cu microunde de $10 \mathrm{~kW}$

\section{Lucian Păunescu $^{1}$, Sorin Mircea Axinte ${ }^{2}$, Marius Florin Drăgoescu ${ }^{3}$, Bogdan Valentin Păunescu ${ }^{4}$}

${ }^{1}$ Daily Sourcing \& Research SRL

95-97 Calea Grivitei street, sector 1, Bucharest 010705, Romania

E-mail: lucianpaunescu16@gmail.com

${ }^{2}$ Department of Applied Chemistry and Materials Science, University „Politehnica” of Bucharest 1-7 Gh. Polizu street, sector 1, Bucharest 011061, Romania

E-mail: sorinaxinte@yahoo.com

${ }^{3}$ Department of Applied Chemistry and Materials Science, University „Politehnica” of Bucharest 1-7 Gh. Polizu street, sector 1, Bucharest 011061, Romania

E-mail:mar_dmf@yahoo.com

${ }^{4}$ Consitrans SA

56 Polona street, sector 1, Bucharest 010504, Romania

E-mail:pnscbogdan@yahoo.com

DOI: $10.37789 /$ rjce.2021.12.4.10

Rezumat. $O$ rețetă de fabricare industrială a pietrișului din spumă de sticlă (CGG) din deșeu de sticlă printr-o tehnică originală neconvențională utilizând simultan un agent de spumare lichid și solid (glicerină și carbonat de calciu) a fost testată intr-un cuptor cu microunde de $10 \mathrm{~kW}$. Utilizând un creuzet ceramic de mari dimensiuni din carbura de siliciu, în interiorul căruia a fost introdusă o matriță metalică conținând amestecul de materie primă fin măcinată și presată, a fost produsă o cantitate mult mai mare de produs spumat. Caracteristicile probelor de CGG au fost densitatea in vrac de 0,20-0,25 $\mathrm{g} / \mathrm{cm}^{3}$, conductivitatea termică de 0,062-0,070 W/m$\cdot \mathrm{K}$ și rezistența la compresiune de 7,17,4 MPa.

Cuvinte cheie: pietriș din spumă de sticlă, încălzire cu microunde, deșeu de sticlă, glicerină, carbonat de calciu.

Abstract. An industrially manufacturing recipe of cellular glass gravel (CGG) from glass waste by an original unconventional heating technique using simultaneously a 
Lucian PAUNESCU, Sorin Mircea AXINTE, Marius Florin DRAGOESCU, Bogdan Valentin PAUNESCU

liquid and solid foaming agent (glycerol and calcium carbonate) was tested on a $10 \mathrm{~kW}$ microwave oven. Using a large silicon carbide ceramic crucible, inside which a metal mold containing the finely ground pressed raw material mixture was inserted, a much higher amount of foamed product was produced. The characteristics of CGG samples were bulk density of $0.20-0.25 \mathrm{~g} / \mathrm{cm}^{3}$, thermal conductivity of $0.062-0.070 \mathrm{~W} / \mathrm{m} \cdot \mathrm{K}$ and compressive strength of 7.1-7.4 MPa.

Key words: foam glass gravel; microwave heating; glass waste; glycerol; calcium carbonate.

\section{Introduction}

In the last decades several major global problems have affected our planet, beginning with the onset of the energy crisis in the 1970s and continuing with the overheating danger due to the destruction of the ozone layer by extenssive and uncontrolled emissions of greenhouse gas (mainly carbon dioxide). The rational energy management [1] has led to the waste recycling (plastic, metal, glass, paper, etc.) and its reuse as a raw material in the manufacturing processes that have its generated. The need for greening the environment by removing large areas of land occupied by the storage of materials considered unusuable has led to the tendency to study the possibilities of turning this waste into new created value materials for other application fields, especially in building and road construction.

The industrial glass manufacturing processes characterized by high consumptions of primary energy uses recycled glass waste as a raw material for energy reasons. According to the literature [2], the manufacture of $1 \mathrm{~kg}$ of new glass requires $4500 \mathrm{~kJ}(1.25 \mathrm{kWh})$, while manufacturing the same amount using recycled glass waste requires only $500 \mathrm{~kJ}(0.139 \mathrm{kWh})$. However, glass waste processing operations such as its selection by color (and implicitly, its chemical composition) are expensive. Given the very large quantities of glass waste in the world and the increasing rate of its generation (especially post-consumer packaging glass representing about $56 \%$ of the total glass amount produced in the EU [3], new domains of using this waste have been found through expansion techniques at temperatures between $800-1100^{\circ} \mathrm{C}$ by addition of a foaming agent [4]. The obtained products (cellular glass) uniquely combine physical, thermal and mechanical characteristics (light weight, low thermal conductivity and high compressive strength) as well as resistance to fire, water, frost and other external agents such as bacteria, acids, insects, rodents, easy handling, low transportation costs, etc. [4], being used in applications in various fields of constructions.

This combination of the properties mentioned above makes cellular glass practically irreplaceable in both contruction (interior and exterior insulation of walls, floors and ceilings of buildings, insulation in the perimeter of buildings, drainage, road and railway construction, sports fields, insulation of underground pipes for energy fluids and underground storagr tanks, bridge abutments, etc.) as well as in 
Expansion of glass waste by the double effect of liquid and solid foaming agents for manufacturing the cellular glass gravel (CGG) in a $10 \mathrm{~kW}$-microwave oven

many other areas such as filters, absorbers, gas sensors, heat exchangers, etc. [4-6], being able to compete with commercially available traditional building materials.

The most used traditional insulation materials [7] are: expanded or extruded polystyrene and phenolic foam (as boards), glass mineral wool (as rolls), hempcrete (as blocks or made in-situ), etc. The mechanical strength and resistance to various external agents of cellular glass are higher compared to all the materials mentioned above. In addition, the energy consumption (about $1500 \mathrm{kWh} / \mathrm{m}^{3}$ ) required to manufacture expanded polystyrene, a commonly used thermal insulation material, is ten times higher than the consumption required for manufacturing the cellular glass [8].

The most recently manufactured type of cellular glass (in the last decade of the $20^{\text {th }}$ century) is the so-called cellular glass gravel or foam glass gravel (CGG) available in the form of lumps with dimensions between 10-75 mm. It has excellent thermal and load bearing properties. It is manufactured from 100\% recycled glass waste being lightweight (bulk density between $0.12-0.25 \mathrm{~g} / \mathrm{cm}^{3}$ ), sustainable (over 50 years) and easy to handle $[5,9]$. The CGG is inert to the freeze-thaw cycle effectively protecting against the impact of frost. Also, it has excellent water drainage properties. Furthermore, the CGG has high values of compressive strength (that can reach 5-6 $\mathrm{MPa}$ ). Generally, all technical books, prospectuses and brochures including CGG characteristics avoid to declare the maximum values of compressive strength, indicating only the minimum values $(0.7-2 \mathrm{MPa})$ [9-12]. The thermal conductivities varies between $0.052-0.12 \mathrm{~W} / \mathrm{m} \cdot \mathrm{K}$ with average values around $0.08 \mathrm{~W} / \mathrm{m} \cdot \mathrm{K}$.

According to [9], over $600,000 \mathrm{~m}^{3}$ of CGG are annually manufactured in Europe (Germany, Switzerland, Austria and the Nordic countries). The main manufacturers [13] are: Geocell Schaumglas (Austria), Misapor Switzerland (Switzerland), Glapor Werk Mitterteich (Germany), Veriso (Germany), Technopor Handels (Austria), Hasopor (Sweden), Glasopor (Norway), Foamit (Finland), Vetropor (Switzerland). In the Nordic countries, road construction is the main market of CGG due to the special harsh climate conditions, which favor freeze-thaw cycles. In order to avoid the negative effect of these cycles on the structural integrity of the road, the thermal insulation of the asphalt layer against the frozen ground, the fast drainage, the absence of capillary action and the structural stability of materials are necessary [13]. Recently, the Misapor Company which produced a wide range of cellular glass announced the decision to focus its production activity only on insulation products of the perimeter of buildings [14].

The manufacturing technique of CGG differs from that of the production of cellular glass for the thermal protection of building walls, floors or ceilings [15], the mixture containing glass waste, foaming agent and other mineral additives being loaded directly on the metal conveyor belt of an tunnel oven. Sintering/foaming of the raw material takes place in the oven heated by conventional methods [10].After reaching the foaming temperature, the material is freely cooled in the oven and then forced cooled by blowing air to create some internal stresses that facilitate the easy breaking of the sintered mass into relatively low lumps (maximum 75-80 $\mathrm{mm}$ ) at the 
end of the conveyor belt. The basic raw material used in the industrial manufacturing processes of CGG is glass waste containing either entirely post-consumer packaging glass, or a mixture composed of this waste type and windows glass waste [13].The manufacturing recipes of the main producers differ by the nature of the foaming agent and additives. Except for Geocell Company, which does not specify the type of foaming agent, Misapor uses gypsum $\left(\mathrm{CaSO}_{4}\right)$, limestone $\left(\mathrm{CaCO}_{3}\right)$ or silicon carbide (SiC) in a weight ratio of $2 \%$. Glapor Werk Mitterteich Company has a manufacturing recipe in which the foaming agent is liquid (glycerol) being used together with sodium silicate (also called "water glass"). Glamaco Company, a very important supplier of industrial equipment for the manufacture of $\mathrm{CGG}$, recommends a recipe with $95 \%$ glass waste, $5 \%$ glycerol, $\mathrm{CaCO}_{3}$ as foaming agents and sodium silicate ("water glass") as an enveloping agent as well as water addition and very low ratio of kaolin powder [16].

As mentioned above, the industrially used heating methods are exclusively conventional (electric resistances or gaseous fuel burning). Unlike these methods, the team of authors has adopted in recent years the unconventional technique of microwave heating the raw material. This technique recognized in the literature [17] as fast, "clean" and economical, but applied to a small extent in industrial processes only for drying or heating at low temperature of some solids, has been used experimentally in the manufacture of FGG as a variant of the manufacturing recipe recommended by Glamaco [16] on a $0.8 \mathrm{~kW}$-microwave oven in the Romanian company Daily Sourcing $\&$ Research.

The experimental results [18] showed that using a powder mixture composed of 93.1 wt. $\%$ colorless glass waste, 1.0 wt. $\%$ glycerol, 4.8 wt. \% water glass, 0.8 wt. \% $\mathrm{CaCO}_{3}, 0.2$ wt. \% kaolin and 14.5 wt. \% water addition, sintered at $834{ }^{\circ} \mathrm{C}$, a CGG with excellent characteristics can be obtained (apparent density of $0.28 \mathrm{~g} / \mathrm{cm}^{3}$, thermal conductivity of $0.063 \mathrm{~W} / \mathrm{m} \cdot \mathrm{K}$, compressive strength of $7.3 \mathrm{MPa}$, water absorption of 4.3 vol. $\%$ and pore size between $0.10-0.35 \mathrm{~mm}$ ). The specific energy consumption was very low $(0.78 \mathrm{kWh} / \mathrm{kg})$.

In the current paper, the authors aimed to test the manufacturing process of CGG by the unconventional microwave heating technique using an available oven with much higher installed power $(10 \mathrm{~kW})$ designed for other operation types, which was adapted to meet the requirements of the experiment. Thus, it was tried to create conditions close to those specific to operations on an industrial scale by substantially enlarging the surface of the material layer subjected to microwave irradiation and the predominantly frontal positioning of the magnetrons. The experiment described further is a new stage of research in the field of foaming glass waste carried out in recent years on a $0.8 \mathrm{~kW}$-microwave oven and has an original character.

\section{Methods and materials}

The very easy dispersion of a liquid foaming agent among the finely ground particles of the glass waste determined the choice of glycerol in the experiment. This organic material $\left(\mathrm{C}_{3} \mathrm{H}_{8} \mathrm{O}_{3}\right)$ decomposes in the oxidizing atmosphere of the oven 
Expansion of glass waste by the double effect of liquid and solid foaming agents for manufacturing the cellular glass gravel (CGG) in a $10 \mathrm{~kW}$-microwave oven

releasing several compounds between carbon dioxide $\left(\mathrm{CO}_{2}\right)$ and pure carbon as well as hydroxyl compounds [19]. The decomposition process begins at low temperature (about $190{ }^{\circ} \mathrm{C}$ ) and continues in several stages up to about $850{ }^{\circ} \mathrm{C}$ [20]. Generally, a carbonic foaming agent such as glycerol has a high affinity for oxygen, having oxidizing conditions in the oven for the premature burning of carbon and affecting the foaming process by the loss of $\mathrm{CO}_{2}$ and carbon monoxide $(\mathrm{CO})$ which leave the material insufficiently heated. For this reason, a 30\% aqueous sodium silicate solution is used to envelope the glass particles. Thus, by heating the decomposition process of glycerol is slowed down and the sintering of the glass is intensified. The addition of water to the starting mixture on the one hand has a role of binder and on the other hand favors the formation of "water gas" containing hydrogen $\left(\mathrm{H}_{2}\right)$ and $\mathrm{CO}$ resulted after the reaction of water vapor with carbon at about $800{ }^{\circ} \mathrm{C}$. The "water gas" contributes to the intensification of the glass foaming.

The solid foaming agent $\left(\mathrm{CaCO}_{3}\right)$ ) initially mixed with the powder glass waste decomposes into $\mathrm{CO}_{2}$ (gas), which forms bubbles in the thermally softened material and calcium oxide $(\mathrm{CaO})$ (solid) which enters in the molten glass composition. The decomposition reaction of $\mathrm{CaCO}_{3}$ is initiated at over $750{ }^{\circ} \mathrm{C}$, according to [21].

Due to the increase of the internal pressure of the gas bubbles under the influence of heating, the viscous material increases its initial volume. At the end of the thermal process, by cooling, the bubbles turn into pores generating a typical porous structure [4]. By its nature, the liquid foaming agent usually contributes to the formation of structures with fine porosity.

The experimental equipment used to manufacture CGG in conditions closer to those of industrial scale production was a $10 \mathrm{~kW}$-microwave oven (Figure 1) existing in the company Daily Sourcing \& Research, designed and used for other types of thermal processes. The oven having the inner space of parallelepiped shape with the volume of about $0.4 \mathrm{~m}^{3}$ is equipped with three magnetrons mounted linearly equidistant on each of the two side walls and four magnetrons mounted equidistantly in the flat vault. Because previous experiments have shown that commercial glass (soda-lime glass) which forms the glass waste is not suitable for complete direct microwave heating causing severe destruction of its internal structure at the foaming temperature [22], a ceramic crucible based on silicon carbide with an outer diameter of $300 \mathrm{~mm}$, a height of $450 \mathrm{~mm}$ and a wall thickness of $10 \mathrm{~mm}$ was placed in a horizontal position inside the oven on an insulating bed made of ceramic fiber mattresses. The outer wall, bottom and opening of the crucible were also intensely thermally protected with ceramic fiber mattresses. The powder mixture was loaded and manually pressed (at about 1-3 MPa) in a metal mold with dimensions of $250 \times 360 \times 50 \mathrm{~mm}$ inserted in a horizontal position inside the ceramic crucible. The constructive scheme of the microwave oven is shown in Figure 2. The thermal protection of the ceramic crucible containing the powder mixture is very important in the case of microwave heating. Both the crucible made of silicon carbide $(\mathrm{SiC})$ and the glass-based mixture have in their composition microwave susceptible materials (mainly $\mathrm{SiC}, \mathrm{Na}_{2} \mathrm{O}, \mathrm{K}_{2} \mathrm{O}$, water, but also $\mathrm{Cr}_{2} \mathrm{O}_{3}, \mathrm{Fe}_{2} \mathrm{O}_{3}$, etc. existing in low ratios), which have the property of 
absorbing and converting the microwave energy into heat. The heating initiation takes place in the core of these materials, the heat propagating volumetrically from the inside to the peripheral areas [23], unlike the conventional heating types where the thermal energy is transferred inversely from the energy source to the material and largely includes massive component parts of the oven (vault, walls, hearth). Because the electromagnetic waves are absorbed only by the microwave susceptible materials by selectivity $[23,24]$, the role of the thermal insulating refractory masonry of the oven is minor.

A thermocouple whose hot welding was fixed on the side wall of the metal mold facilitated controlling the temperature of the process.

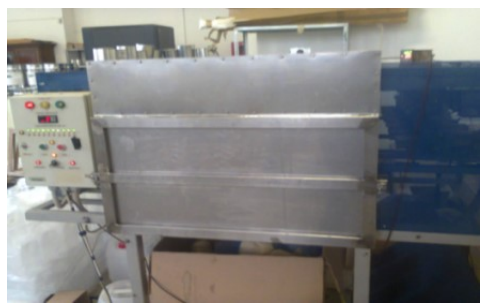

Fig. 1

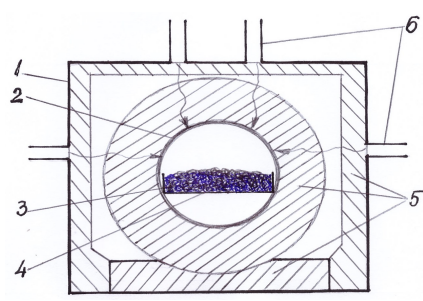

Fig. 2

Fig. 1. Overall image of the $10 \mathrm{~kW}$-microwave oven Fig. 2. Constructive scheme of the microwave oven:

1 - oven wall; 2 - $\mathrm{SiC}$ ceramic tube; 3 - pressed powder material; 4 - metal mold; 5 - ceramic fiber mattress; 6 - waveguide.

The determination of the physical, thermal, mechanical and microstructural features of the CGG lumps was performed by usual methods. The heat-flow meter method (ASTM E1225-04) was used for measuring the thermal conductivity and the compressive strength could be determined by the use of a TA.XTplus Texture Analyzer (ASTM C552-17). The bulk density was measured by the traditional method of weighing a batch of lumps completely loaded into a vessel of known volume and dividing the batch mass by the inner volume of the vessel [25]. The porosity was calculated by the comparing method of the true and bulk density [26]. The volumetric percentage of the water absorption for 24 hours was measured by the water immersion method (ASTM D570). The configuration of the CGG sample microstructures was examined with an ASONA 100X Zoom Smartphone Digital Microscope.

As mentioned, a manufacturing recipe previously applied on the $0.8 \mathrm{~kW}$ microwave oven composed of packaging glass waste as raw material, glycerol and $\mathrm{CaCO}_{3}$ as foaming agents (liquid and solid), an aqueous solution of sodium silicate ("water glass") as an enveloping agent, kaolin powder (in a very low ratio) as a thermal protection agent for ceramic materials [27] and water addition as a binder [18], was also tested in conditions closer to those on an industrial scale created by the 10 $\mathrm{kW}$-microwave oven described above.

In this experiment, the glass waste was a mixture composed of colorless glass $(50 \%)$, green glass $(20 \%)$ and amber glass $(30 \%)$ representing approximately the proportion of this waste recycled in Romania. The chemical composition of the three glass types is shown in Table 1. 
Expansion of glass waste by the double effect of liquid and solid foaming agents for manufacturing the cellular glass gravel (CGG) in a $10 \mathrm{~kW}$-microwave oven

Table 1

Chemical composition of the glass waste types

\begin{tabular}{|c|c|c|c|}
\hline \multirow{2}{*}{ Composition } & \multicolumn{3}{|c|}{ Glass waste type, wt.\% } \\
\cline { 2 - 4 } & Colorless & Green & Amber \\
\hline $\mathrm{SiO}_{2}$ & 71.7 & 71.8 & 71.1 \\
\hline $\mathrm{Al}_{2} \mathrm{O}_{3}$ & 1.9 & 1.9 & 2.0 \\
\hline $\mathrm{CaO}$ & 12.0 & 11.8 & 12.1 \\
\hline $\mathrm{Fe}_{2} \mathrm{O}_{3}$ & - & - & 0.2 \\
\hline $\mathrm{MgO}$ & 1.0 & 1.2 & 1.1 \\
\hline $\mathrm{Na}_{2} \mathrm{O}$ & 13.3 & 13.1 & 13.3 \\
\hline $\mathrm{K}_{2} \mathrm{O}$ & - & 0.1 & 0.1 \\
\hline $\mathrm{Cr}_{2} \mathrm{O}_{3}$ & 0.05 & 0.09 & - \\
\hline $\mathrm{SO}_{3}$ & - & - & 0.05 \\
\hline Other oxides & 0.05 & 0.01 & 0.05 \\
\hline
\end{tabular}

The glass waste processing (selection by color, breaking, coarse grinding, thermal washing at $250{ }^{\circ} \mathrm{C}$, fine grinding and sieving at pore size below $100 \mu \mathrm{m}$ ) was performed in the Romanian company Bilmetal Industries SRL Popesti Leordeni-Ilfov.

$\mathrm{CaCO}_{3}$ commercially purchased with a granulation below $40 \mu \mathrm{m}$ was used without a supplementary reduction of the grain size. The commercial kaolin purchased from the market as a very fine powder (below $10 \mu \mathrm{m}$ ) was added in an extremely low proportion to the solid mixture due to the ability of the aqueous suspension of kaolinite (from the composition of kaolin) to provide a thermal protection of the ceramic material. The chemical composition of the kaolin contains: $57.6 \% \mathrm{SiO}_{2} ; 37.8 \%$ $\mathrm{Al}_{2} \mathrm{O}_{3} ; 0.35 \% \mathrm{CaO} ; 0.86 \% \mathrm{Fe}_{2} \mathrm{O}_{3} ; 0.6 \% \mathrm{MgO} ; 1.8 \% \mathrm{~K}_{2} \mathrm{O} ; 0.3 \% \mathrm{P}_{2} \mathrm{O}_{5}$ and $0.7 \%$ other oxides [28].

The glycerol available in liquid state, together with the aqueous solution of water glass, both purchased from the market, were prepared in a separate vessel in which the water was added as a binder. After mixing with an electrically operated device, the liquid component was poured over the solid powder mixture and the wet material was further mixed for 10-15 min until a homogeneous viscous paste was obtained.

The materials dosage distributed into four experimental variants was influenced by the results previously obtained by the same team of authors when testing the manufacture of a glass foam of CGG type on the $0.8 \mathrm{~kW}$-microwave oven using manufacturing recipes based on the combination of a solid foaming agent $\left(\mathrm{CaCO}_{3}\right)$ and a liquid agent (glycerol) associated with water glass as an enveloping agent [18]. The variants tested in that paper were slightly different, $\mathrm{CaCO}_{3}$ having values between 0.8 $1.1 \mathrm{wt}$. \%, glycerol between 1.0-1.1 wt. \% (practically constant) and water glass in the range 3.0-4.8 wt. \%. The ratios of kaolin and water addition were kept constant at 0.2 and $14.5 \mathrm{wt} . \%$, respectively. Practically all four tested variants led to excellent results, mentioned above. For this reason, the experimental variants adopted for testing on the $10 \mathrm{~kW}$-microwave oven (Table 2) had values around those successfully experienced on a very small scale. 
Lucian PAUNESCU, Sorin Mircea AXINTE, Marius Florin DRAGOESCU, Bogdan Valentin PAUNESCU

Table 2

Material dosage of the experimental variants

\begin{tabular}{|c|c|c|c|c|}
\hline Material (wt. \%) & Variant 1 & Variant 2 & Variant 3 & Variant 4 \\
\hline Glass waste & 93.5 & 93.4 & 93.3 & 93.2 \\
\hline $\mathrm{CaCO}_{3}$ & 0.8 & 0.9 & 1.0 & 1.1 \\
\hline Kaolin powder & 0.2 & 0.2 & 0.2 & 0.2 \\
\hline Glycerol & 1.0 & 1.0 & 1.0 & 1.0 \\
\hline Water glass & 4.5 & 4.5 & 4.5 & 4.5 \\
\hline Water addition & 14.5 & 14.5 & 14.5 & 14.5 \\
\hline
\end{tabular}

The sintering/foaming temperature experimentally determined on the $0.8 \mathrm{~kW}$ microwave oven was in a narrow range of values $\left(834-841{ }^{\circ} \mathrm{C}\right)$, being also adopted in the case of testing on the $10 \mathrm{~kW}$-oven.

Unlike the low amount of the wet starting materials (538 g) used in the experiment performed on the $0.8 \mathrm{~kW}$-microwave oven, the transition to a higher stage of experimentation on a $10 \mathrm{~kW}$-microwave equipment allowed the preparation of a significantly larger amount of materials reaching $4.50 \mathrm{~kg}$ (including also the addition of water).

\section{Results and discussion}

The main functional parameters of the experimental manufacture of CGG in the $10 \mathrm{~kW}$-microwave equipment adapted according to the description presented above are shown in Table 3.

Table 3

Main functional parameters of the experimental process

\begin{tabular}{|c|c|c|c|c|}
\hline Parameter & Variant 1 & Variant 2 & Variant 3 & Variant 4 \\
\hline Wet raw material/CGG amount $(\mathrm{kg})$ & $4.50 / 3.87$ & $4.50 / 3.85$ & $4.50 / 3.87$ & $4.50 / 3.88$ \\
\hline Sintering/foaming temperature $\left({ }^{\circ} \mathrm{C}\right)$ & 834 & 836 & 838 & 840 \\
\hline Heating time $(\mathrm{min})$ & 46.5 & 48 & 50 & 54 \\
\hline $\begin{array}{c}\text { Average rate }\left({ }^{\circ} \mathrm{C} / \mathrm{min}\right) \\
\text {-heating }\end{array}$ & 17.5 & 17.0 & 16.4 & 15.2 \\
-cooling & 7.3 & 7.2 & 7.0 & 7.0 \\
\hline $\begin{array}{c}\text { Index of volume growth } \\
\text { Specific energy consumption } \\
(\mathrm{kWh} / \mathrm{kg})\end{array}$ & 1.45 & 1.60 & 1.70 & 1.95 \\
\hline
\end{tabular}

Under the conditions of pre-establishing temperature values in the optimal range $\left(834-840^{\circ} \mathrm{C}\right.$ ) experimentally determined on a small scale [18], the other functional parameters of the process shown in Table 3 were modified. The new positioning of the waveguides and their distribution on the walls and vault of the oven, the new type of screen made of microwave susceptible material as well as the large internal volume of the oven and the significant increase of the heated material amount compared to the experimental conditions offered by the $0.8 \mathrm{~kW}$-microwave oven influenced the main functional parameters (process time, average heating rate and specific energy consumption). As expected, the process time increased to 46.5-54 min compared to $34-37.5 \mathrm{~min}$ in the reference experiment, the average heating rate 
Expansion of glass waste by the double effect of liquid and solid foaming agents for manufacturing the cellular glass gravel (CGG) in a $10 \mathrm{~kW}$-microwave oven

decreased to $15.2-17.5^{\circ} \mathrm{C} / \mathrm{min}$ compared to $21.9-23.9^{\circ} \mathrm{C} / \mathrm{min}$, despite improving the thermal protection of the ceramic crucible and the specific energy consumption increased to $1.57-1.82 \mathrm{kWh} / \mathrm{kg}$ compared to $0.78-0.85 \mathrm{kWh} / \mathrm{kg}$, but its values are still considered economical. The authors of the paper [17] believe that a suitable industrialscale microwave equipment should contribute to increasing the energy efficiency of the heating process by up to $25 \%$ compared to a low-power domestic microwave oven (less than $1 \mathrm{~kW}$ ). The volume growth index of the starting material was between 1.45 1.95 slightly higher compared to the reference experiment (1.30-1.60).

The average cooling rate of CGG was increased to $7.0-7.3{ }^{\circ} \mathrm{C} / \mathrm{min}$ by fully opening the oven door after completing the heating process and then removing the metal mold containing the foamed material. The effect of this cooling mode was the partial cracking of the CGG, better observable in the case of industrial processes manufactured in conveyor belt ovens by conventional heating techniques.

The appearance of the CGG samples corresponding to the four experimental variants is shown in Figure 3. The materials obtained by heating at lower temperatures are more dense and compact, while those heated at higher temperatures are slightly more porous and less dense.

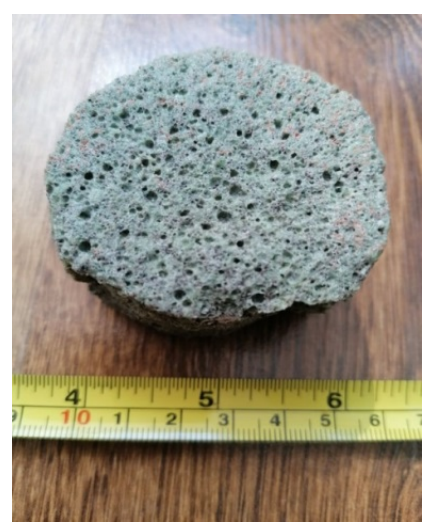

a

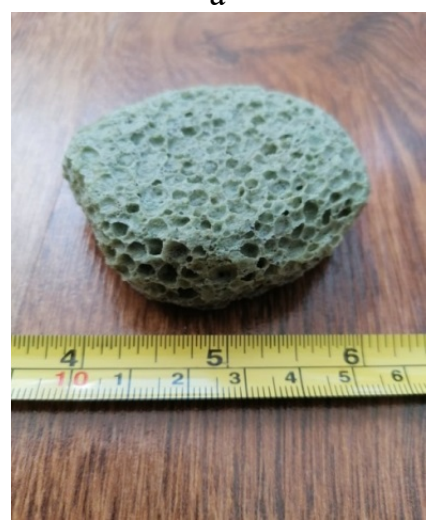

c

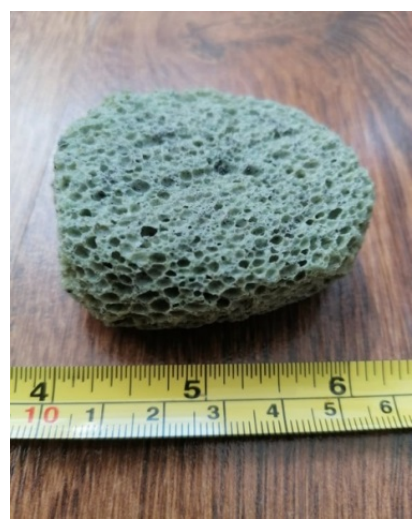

b

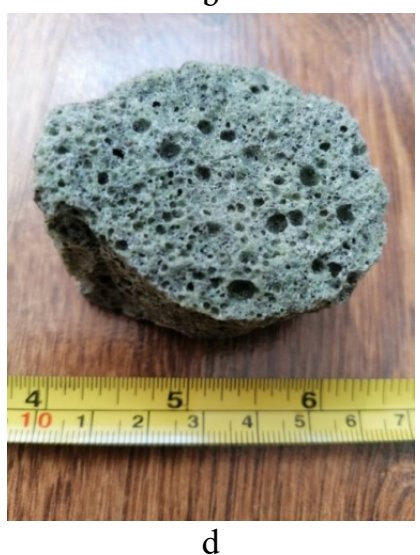

d

Fig. 3. Appearance pictures of the CGG samples $\mathrm{a}$ - variant $1 ; \mathrm{b}$ - variant 2 ; c - variant $3 ; \mathrm{d}$ - variant 4 . 
Lucian PAUNESCU, Sorin Mircea AXINTE, Marius Florin DRAGOESCU, Bogdan Valentin PAUNESCU

The main physical, thermal, mechanical and microstructural features of the CGG lump samples are presented in Table 4.

Table 4

Main physical, thermal, mechanical and microstructural features of the CGG lump samples

\begin{tabular}{|c|c|c|c|c|c|c|}
\hline Variant & $\begin{array}{c}\text { Bulk } \\
\text { density } \\
\left(\mathrm{g} / \mathrm{cm}^{3}\right)\end{array}$ & Porosity & $\begin{array}{c}\text { Thermal } \\
\text { conductivity } \\
(\mathrm{W} / \mathrm{m} \cdot \mathrm{K})\end{array}$ & $\begin{array}{c}\text { Compressive } \\
\text { strength } \\
(\mathrm{MPa})\end{array}$ & $\begin{array}{c}\text { Water } \\
\text { absorption } \\
(\text { vol. \%) }\end{array}$ & $\begin{array}{c}\text { Pore size } \\
(\mathrm{mm})\end{array}$ \\
\hline 1 & 0.25 & 85.8 & 0.070 & 7.4 & 2.3 & $0.30-0.90$ \\
\hline 2 & 0.23 & 86.7 & 0.069 & 7.4 & 2.4 & $0.40-1.40$ \\
\hline 3 & 0.20 & 88.2 & 0.060 & 7.2 & 2.9 & $1.00-1.80$ \\
\hline 4 & 0.21 & 87.7 & 0.062 & 7.1 & 2.8 & $1.80-3.80$ \\
\hline
\end{tabular}

The analysis of the data in Table 4 shows that the CGG lump samples obtained by the unconventional microwave heating method correspond to the requirements of cellular glass gravels usable as thermal insulation materials under mechanical stress conditions. The bulk density (between $0.20-0.25 \mathrm{~g} / \mathrm{cm}^{3}$ ) has values located towards the upper limit of this physical characteristic industrially obtained, but it is compensated by the very high level of the compressive strength (7.1-7.4 $\mathrm{MPa}$ ) above the maximum limit (of about $6 \mathrm{MPa}$ ) required for CGG lumps.

The thermal insulation characteristics of CGG samples, influenced by the low thermal conductivity (between $0.062-0.070 \mathrm{~W} / \mathrm{m} \cdot \mathrm{K}$ ), low bulk density and high porosity (85.8-88.2 $\%$ ) indicate a suitable material in terms of quality. In addition, the water absorption has low values (2.3-2.9 vol. \%) being at the level required for these insulating material types. The low pore size of CGG lumps characterizes variants $1-2$, in which glycerol $(1 \%)$ was used together with lower proportions of $\mathrm{CaCO}_{3}(0.8-0.9 \%)$, while higher pore sizes were obtained in variants 3-4, in which the $\mathrm{CaCO}_{3}$ proportions increased slightly to $1.0-1.1 \%$.

The microstructural configuration of the CGG samples is shown in Figure 4.

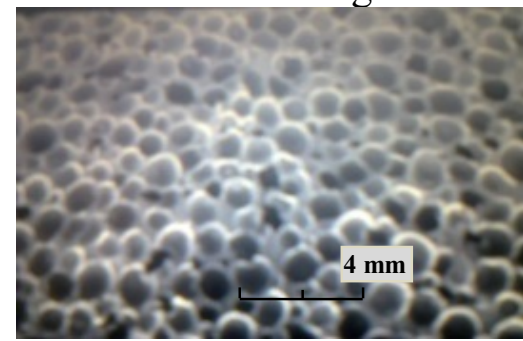

a

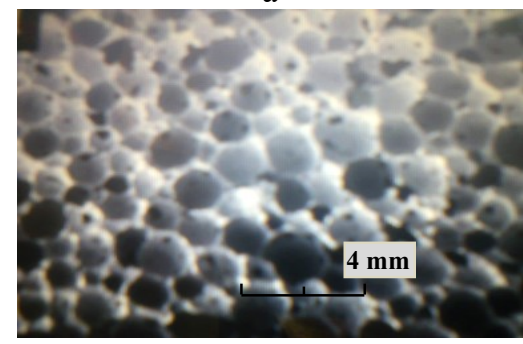

C

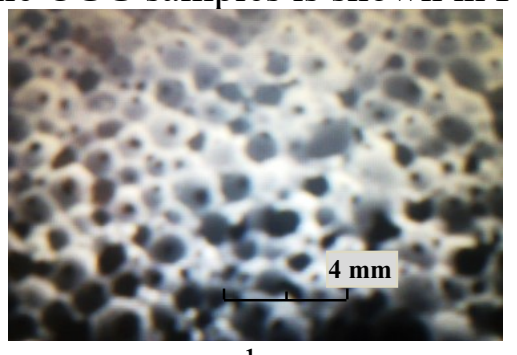

b

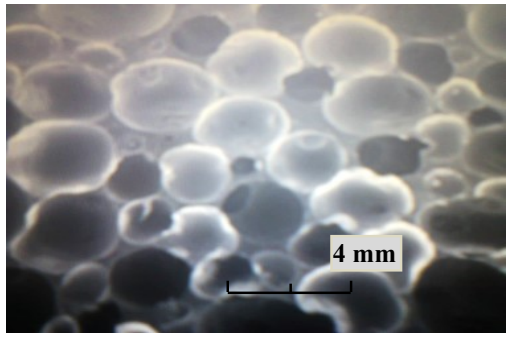

d

Fig. 4. Microstructural configuration of the CGG samples $\mathrm{a}$ - variant $1 ; \mathrm{b}$ - variant $2 ; \mathrm{c}$ - variant $3 ; \mathrm{d}$ - variant 4 . 
Expansion of glass waste by the double effect of liquid and solid foaming agents for manufacturing the cellular glass gravel (CGG) in a $10 \mathrm{~kW}$-microwave oven

\section{Conclusion}

In the current stage of the research, the authors aimed at the experimental production of CGG corresponding to the market requirement in terms of quality under the conditions of significant increase of processed material amount compared to the previous test on a small-scale microwave oven. The originality of the research presented in the work is the use of an unconventional microwave heating technique unlike the conventional techniques commonly applied by all world industrial manufacturers. The experiment was performed on a $10 \mathrm{~kW}$-microwave oven existing in the Daily Sourcing \& Research Company. The authors followed the CGG manufacturing process especially in terms of quality. The main features of the CGG lump samples were: bulk density of $0.20-0.25 \mathrm{~g} / \mathrm{cm}^{3}$, thermal conductivity of $0.062-$ $0.070 \mathrm{~W} / \mathrm{m} \cdot \mathrm{K}$, compressive strength of 7.1-7.4 MPa. These features, similar to industrially manufactured products by conventional techniques, are suitable for their use as CGG lumps.

\section{References}

[1] S. De Bruyn, C. Jongsma, B. Kampman , B. Görlach, J-E. Thie, „Energy-Intensive IndustriesChallenge and Opportunities in Energy Transition", Policy Department for Economic, Scientific and Quality of Life Policies, European Parliament, Luxembourg, 2020. http://www.europarl.europa.eu/supporting-analyses

[2] G. Scarinci, G. Brusatin, L. Barbieri, A. Corradi, I. Lancellotti, P. Colombo, S. Hreglich, R. Dall'Igna, „Vitrification of industrial and natural wastes with production of glass fibres", Journal of the European Ceramic Society, vol. 20, no. 14, 2000, pp. 2485-2490.

[3] E. Rodriguez Vieitez, P. Eder, A. Villanueva, H. Saveyn, „End-of-waste criteria for glass cullet: Technical proposals", Publication Office of the European Union, Luxembourg, 2011.

[4] G. Scarinci, G. Brusatin, E. Bernardo, „Glass Foams” in Cellular Ceramics: Structure, Manufacturing, Properties and Applications, Wiley-VCH, Verlag GmbH Co KGaA, Weinheim, Germany, 2005, pp. 158-176.

[5] *** Geocell Foam Glass Gravel-High Performance in Every Aspect, UK Brochure, July 2017. https://www.mikewye.co.uk/wp-content/uploads/2014/09/GEOCELL-Brochure-UK-Sept16.pdf

[6] *** Geocell Foam Glass, 2016. https://www.foamglassgravel.com/en/

[7] *** Insulation materials and their properties, 2017. http://www.greenspec.co.uk/buildingdesign/insulation-materials-thermal-properties

[8]*** Fabricarea sticlei celulare, Energocell, Debrecen, Hungary, 2019. http://www.energocell.hu/ro/fabricarea-sticlei-celulare

[9] H. Hibbert, „Understanding the production and use of Foam Glass Gravel across Europe and opportunities in the UK", Final Report, 2016. http://static1.squarespace.com/static/584175382994caab5d6b2427/t592eb355db29d6b2ff34f305 $11496232791849 /$ Foam+Glass+Gravel+Production+in+Europe+and+opportunities + in + the + UK ++ Mike+Hibbert+July+2016+J+C+Dawes+Report+Final+Version.pdf

[10]A. Zegowitz, „Cellular glass aggregates serving as thermal insulation and a drainage layer”, Buildings, vol. XI, 2010, pp. 1-8. https://web.oml.gov $>$ conf-archive $>48$ Zegowitz

[11]*** Glapor Schaumglasprodukte, 2017. http://www.glapor.de/en/produkte/cellular-glass-gravel

[12]*** Environmental Product Declaration-Glapor cellular glass, Glapor Werk Mitterteich GmbH, December 2017. 
Lucian PAUNESCU, Sorin Mircea AXINTE, Marius Florin DRAGOESCU, Bogdan Valentin PAUNESCU

https://www.foamrox.no/wp-content/uploads/2020/12/2017-EPD_GLAPOR-cellular-glass.pdf

[13]Felicia Cosmulescu, L. Paunescu, M.F. Dragoescu, S.M. Axinte, „Comparative analysis of the foam glass gravel types experimentally produced by microwave irradiation", Journal of Engineering Studies and Research, vol. 26, no. 3, 2020, pp. 58-68.

[14]*** Misapor, 2019. http://www.archiexpo.com/soc/misapor-78710.html

$[15]^{* * *}$ Foamglas for the Building Envelope-Cellular Glass Insulation Guide, 2016. https://www.reinish-

co.it/fileadmin/user_upload/pdfs/Foamglas_ENG_diverse/FOAMGLAS for the Building_Env elope.pdf

[16]*** Glamaco, Coswig, Germany, 2014. https://www.Glamaco.com/backend/wpcontent/uploads/2014/02/Foam-Glass,pdf

[17]Oxana V. Kharissova, B.I. Kharissov, J.J. Ruiz Valdés, „Reviews: The use of microwave irradiation in the processing of glasses and their composites", Industrial \& Engineering Chemistry Research, vol. 49, no. 4, 2010, pp. 1457-1466.

[18]L. Paunescu, S.M. Axinte, M.F. Dragoescu, F. Cosmulescu, B.V. Paunescu, „Simultaneous use of liquid and solid foaming agents by a nonconventional technique to obtain a high-strength glass foam with fine porosity", Nonconventional Technologies Review, vol. 25, no. 2, 2021, pp. 3-9.

[19]Svitlana Karandashova, B.M. Goltsman, E.A. Yatsenko, „Analysis of influence of foaming mixture components on structure and properties of foam glass", IOP Conference Series: Materials Science and Engineering, vol. 262, 2017, pp. 1-6. https://www.iopscience.iop.org $>$ article $>262$

[20]B. Dou, V. Dupont, P.T. Williams, H. Chen, Y. Ding, „Thermogravimetric kinetics of crude glycerol", Bioresource Technology, vol. 100, no. 9, 2008, pp.2613-2620. http://dx.doi.org/10.1016/j.biortech.2008.11.037

[21]K.S.P. Karunadasa, C.H. Manoratne, H.M.T.G.A. Pitawala, R.M.G. Rappakse, „Thermal decomposition of calcium carbonate (calcite polymorph) as examined by in-situ hightemperature X-ray powder diffraction”, Journal of Physics and Chemistry of Solide, vol. 134, 2019, pp. 21-28.

[22]L. Paunescu, S.M. Axinte, B.T. Grigoras, M.F. Dragoescu, A. Fiti, „Testing the use of microwave energy to produce foam glass", European Journal of Engineering and Technology, vol. 5, no. 4, 2007, pp. 8-17.

[23]Helen J. Kitchen, S.R. Vallance, J.L. Kennedy, N. Tapia-Ruiz, L. Carassiti, A. Harrison, A.G. Whittaker, T.D, Drysdale, S.V. Kingman, D.H. Gregory, „Modern microwave methods in solisstate inorganic materials chemistry: From fundamentals to manufacturing", Chemical Reviews, vol. 114, no. 2, 2014, pp. 1170-1206.

[24]D.A. Jones, T.P. Lelyveld, S.D., Mavrofidis, S.W. Kingman, N.J. Miles, „Microwaves heating applications in environmental engineering-a review", Resources, Conservation and Recycling, vol. 34, no. 2, 2002, pp. 75-90.

[25]A. Scorgins, „Bulk density of industrial minerals: Reporting in accordance with the 2007 SME Guide", 2015. https://www.csa.global.com/wp-content/uploads/2015/07/Bulk-density-ofindustral-minerals-Reporting-in-accordance-with-the-2007-SME-Guide.pdf

[26]L.M. Anovitz, D.R. Cole, „Characterization and analysis of porosity and pore structures”, Reviews in Mineralogy and Geochemistry, vol. 80, 2005, pp. 61-164.

[27]W.B. Jepson, „Kaolins:their properties ans uses”, Philosophical Transactions of the Royal Society A, vol. 311, 1984, pp. 411-432. https://www.jstor.org $>$ stable

[28]S. Yahaga, S.S. Jikan, N.A. Badarulzaman, A.D. Adamu, „Chemical composition of particle size analysis of kaolin", Traektoriâ Nauki-Path of Science, vol. 3, no. 10, 2017. https://www.doi.org/10.22178/pas.27-1 